\title{
Cystobasidiomycetes yeasts from Patagonia (Argentina): description of Rhodotorula meli sp. nov. from glacial meltwater
}

Correspondence

Diego Libkind

libkind@crub.uncoma.edu.ar

\section{Diego Libkind, ${ }^{1}$ José Paulo Sampaio ${ }^{2}$ and Maria van Broock ${ }^{1}$}

\author{
${ }^{1}$ Laboratorio de Microbiología Aplicada y Biotecnología, Instituto de Investigaciones en \\ Biodiversidad y Medio Ambiente (INIBIOMA), UNComahue-CONICET, Quintral 1250, (8400), \\ Bariloche, Río Negro, Argentina \\ ${ }^{2}$ Centro de Recursos Microbiológicos, Departamento de Ciências da Vida, Faculdade de Ciências e \\ Tecnologia, Universidade Nova de Lisboa, 2829-516 Caparica, Portugal
}

\section{INTRODUCTION}

During a survey of carotenogenic yeasts inhabiting aquatic environments of glacier origin in Patagonia (Argentina), four novel yeast species were detected (Libkind et al., 2003). Three of these species have already been described as Sporobolomyces patagonicus, Sporidiobolus longiusculus (Libkind et al., 2005a) and Cystofilobasidium lacusmascardii (Libkind et al., 2009a). The fourth species was assigned to the basidiomycetous genus Rhodotorula based on phenotypic and molecular studies (Libkind et al., 2003). This species clustered phylogenetically within the class Cystobasidiomycetes (subphylum Pucciniomycotina), with a close relationship to the Sakaguchia clade. This group is related to the order Erythrobasidiales (which includes Rhodotorula minuta) and currently comprises three species: Sakaguchia dacryoidea and two species of the genus Rhodotorula, Rhodotorula lamellibrachii and Rhodotorula oryzae. Here, a novel yeast species, strain CRUB $1032^{\mathrm{T}}$, isolated from freshwater and related to the Sakaguchia group is described and the name Rhodotorula meli sp. nov.

Abbreviations: ITS, internal transcribed spacer; MSP-PCR, microsatellite-primed PCR; PSC, starch-like compounds.

The GenBank/EMBL/DDBJ accession numbers for the sequences determined in this study are FJ807684 (Rhodotorula slooffiae PYCC 476126 S rRNA gene), and FJ807683, FJ807685, FJ807686 and FJ807687 (complete ITS region, 5.8S, 18S and 26S rRNA genes of $R$. meli CRUB 1032 ${ }^{\top}, R$. slooffiae PYCC 4761, R. pinicola CRUB 1028 and $R$. slooffiae CRUB 1029, respectively). is proposed. Physiological and molecular characterization of additional freshwater yeast isolates of the class Cystobasidiomycetes from Patagonia and of collection strains of closely related species is also included in this work.

\section{METHODS}

Yeast isolation. Yeast strains of the genus Rhodotorula used in this report were isolated from freshwater environments of glacial origin in north-western Patagonia by filtering subsurface water samples, as described by Libkind et al. (2003), or were obtained from international culture collections (see Table 1). Isolate CRUB $1032^{\mathrm{T}}$ was recovered in a 2002 summer survey. Further attempts to obtain additional strains of isolate CRUB $1032^{\mathrm{T}}$ in subsequent years $(2003$ and 2004) were carried out in the Ventisquero Negro glacier using conventional culture media (Libkind et al., 2003) or specifically designed medium: yeast nitrogen base (YNB) D-glucuronate agar (YNB, $67 \mathrm{~g}^{-1}$; D-glucuronate, $5 \mathrm{~g}^{-1}$; agar, $15 \mathrm{~g}^{-1}$ ) containing $0.02 \%$ chloramphenicol, $\mathrm{pH}$ 5. For the latter culture medium, larger volumes of water were filtered (up to 11 ).

Physiological and biochemical characteristics. The colour of cultures was assessed using the mycological colour chart of Rayner (1970). Complete physiological characterization of $R$. meli sp. nov. CRUB $1032^{\mathrm{T}}$, Rhodotorula slooffiae CBS $5706^{\mathrm{T}}$, Rhodotorula laryngis CBS $2221^{\mathrm{T}}$, R. lamellibrachii CBS 9598 ${ }^{\mathrm{T}}, R$. slooffiae CRUB 1029 and Rhodotorula pinicola CRUB 1028 was performed. Tests were carried out in liquid media according to Yarrow (1998). Additional assimilation tests using aldaric acids and aromatic compounds were performed as described by Fonseca (1992) and Sampaio (1999), 
Table 1. List of strains studied and their origin

R., Rhodotorula, O., Occultifur, S., Sakaguchia.

\begin{tabular}{|c|c|c|}
\hline Species & Strain no. & Origin \\
\hline O. externus & CBS $8732^{\mathrm{T}}$ & Plant litter, Sintra, Portugal \\
\hline O. externus & PYCC 4557 & Plant litter, Sesimbra, Portugal \\
\hline O. externus & PYCC 4823 & Shore seawater, Portugal \\
\hline R. lactosa & CBS $5826^{\mathrm{T}}$ & Air \\
\hline R. lamellibrachii & CBS $9598^{\mathrm{T}}$ & Tubeworm, deep-sea floor, Japan \\
\hline R. laryngis & CRUB 1105 & Ilón lake, Patagonia \\
\hline R. laryngis & CRUB 1183 & Ventisquero Negro glacier, Patagonia \\
\hline R. laryngis & CBS $2221^{\mathrm{T}}$ & Laryngeal swab, human male, Norway \\
\hline R. laryngis & CBS 5695 & Child's faeces, Hungary \\
\hline R. laryngis & CBS $8020(=J C M ~ 3778)$ & Seawater, sea off Sweden \\
\hline R. marina & CBS $2365^{\mathrm{T}}$ & Shrimp, Gulf of Mexico \\
\hline R. meli & CRUB $1032^{\mathrm{T}}\left(=\mathrm{CBS} 10797^{\mathrm{T}}=\mathrm{JCM} 15319^{\mathrm{T}}\right)$ & Ventisquero Negro glacier, Patagonia \\
\hline R. minuta & CBS $319^{\mathrm{T}}$ & Atmosphere, Tokyo, Japan \\
\hline R. minuta & CBS 4407 & Atmosphere, Shinjuku, Japan \\
\hline R. minuta & CBS 2177 & Shrimp, Gulf of Mexico Aransas Bay \\
\hline R. minuta & CBS 4478 & Seawater, USA, off Florida \\
\hline R. minuta & CRUB 25 & Mascardi lake, Patagonia \\
\hline R. minuta & CRUB 76 & Mascardi lake, Patagonia \\
\hline R. minuta & CRUB 1136 & Negra lake, Patagonia \\
\hline R. pinicola & CRUB 1028 & Nahuel Huapi lake, Patagonia \\
\hline R. slooffiae & CBS $5706^{\mathrm{T}}$ & Throat swab, human male, Hungary \\
\hline R. slooffiae & PYCC 4887 (=JCM 3779) & Unknown \\
\hline R. slooffiae ${ }^{*}$ & CBS 8019 & Seawater, sea off Sweden \\
\hline R. slooffiae & PYCC 4761 & Paper mill effluent, Setúbal, Portugal \\
\hline R. slooffiae & PYCC 4762 & Plant litter, Sesimbra, Portugal \\
\hline R. slooffiae & PYCC 4763 & Pine cone, Oeiras, Portugal \\
\hline R. slooffiae & CRUB 1029 & Nahuel Huapi lake, Patagonia \\
\hline R. pallida & CBS $320^{\mathrm{T}}$ & Mycotic nodule in white rat \\
\hline S. dacryoidea & CBS $6353^{\mathrm{T}}$ & Seawater, Antarctic \\
\hline S. dacryoidea & CBS 6356 & Seawater, Antarctic \\
\hline S. dacryoidea & A41 & Seawater, Faro, Portugal \\
\hline
\end{tabular}

${ }^{*}$ Deposited as R. minuta in CBS.

respectively. Mycosporine synthesis in strain CRUB $1032^{\mathrm{T}}$ was studied previously by Libkind et al. (2005b).

Molecular characterization. For PCR fingerprinting, the microsatellite-primed (MSP)-PCR technique was employed. The DNA extraction protocol, primers, PCR and electrophoresis conditions and gel image analysis procedures were those reported in Sampaio et al. (2001). For DNA sequence analysis, DNA extraction, PCR amplification, purification and cycle sequencing followed the protocol of Sampaio et al. (2001). DNA was amplified using primers ITS5 (5'GGAAGTAAAAGTCGTAACAAGG) and LR6 (5'-CGCCAGTTCTGCTTACC). Cycle sequencing of the $600-650$ bp region at the $5^{\prime}$ end of the $26 \mathrm{~S}$ rDNA (D1/D2 domains) employed forward primer NL1 (5'-GCATATCAATAAGCGGAGGAAAAG) and reverse primer NL4 (5'-GGTCCGTGTTTCAAGACGG). The internal transcribed spacer (ITS) region was sequenced using the forward primer ITS1 $\left(5^{\prime}\right.$ TCCGTAGGTGAACCTGCGG) and the reverse primer ITS4 (5'TCCTCCGCTTATTGATATGC). Sequences were obtained using an Amersham Pharmacia ALF express II automated sequencer using standard protocols. Alignments were made with BioEdit V7.0.9 and corrected visually (Hall, 1999). Phylogenetic analysis was carried out using the neighbour-joining method (Saitou \& Nei, 1987).
Evolutionary distances were computed using the Kimura twoparameter method (Kimura, 1980) and bootstrap analysis was inferred from 1000 replicates (Felsenstein, 1985). All positions containing gaps or missing data were eliminated from the dataset (complete deletion option). Phylogenetic analyses were conducted with MEGA4 (Tamura et al., 2007).

\section{RESULTS AND DISCUSSION}

\section{Phenotypic and molecular investigations}

During our investigations on the diversity of carotenogenic yeasts in Patagonian freshwater habitats, eight strains producing light pink colonies were isolated. A notable characteristic shared by the eight strains was that colonies in malt extract-yeast extract-peptone agar were highly mucous and sticky; this characteristic was less evident in richer culture media (i.e. yeast extract-malt extract agar or yeast extract-peptone-glucose). All strains showed 
physiological characteristics that resembled those of the Cystobasidiomycetes yeasts (Bauer et al., 2006), namely, the absence of inositol and nitrate assimilation, and production of starch-like compounds (PSC), and the presence of D-glucuronate assimilation and mycosporine synthesis. Libkind et al. (2005b) showed that the ability to synthesize mycosporines and the lack of PSC are sufficient criteria to assign a red-pigmented yeast isolate to the class Cystobasidiomycetes.

MSP-PCR fingerprinting studies were performed on the eight Patagonian strains and on several type and collection strains of yeast species belonging to the class Cystobasidiomycetes and related taxonomic groups. For R. minuta, R. slooffiae, $R$. laryngis and Sakaguchia dacryoidea, more or less conserved MSP-PCR banding patterns were obtained, given that most strains of each species had similar profiles (Fig. 1). This result highlights the usefulness of the MSP-PCR technique (with the M13 primer) for the rapid grouping and identification of relevant yeast species of the class Cystobasidiomycetes. Strain CBS 8019, deposited as R. minuta, had a similar DNA profile to $R$. slooffiae strains, suggesting that it might have been misidentified. Among the Patagonian strains, five different groups of DNA banding patterns were revealed (MSP-PCR groups). A comparison of the MSP-PCR profiles of type strains with those of the Patagonian strains showed that the MSP-PCR group that included isolates CRUB 1105 and CRUB 1183 had DNA patterns similar to $R$. laryngis, whereas the MSP-PCR group that included isolates CRUB 25, CRUB 76 and CRUB 1136 shared identical DNA patterns with $R$. minuta. These results were confirmed by sequence analysis of the D1/D2 region of the 26S rDNA (Fig. 2) and the ITS region (data not shown). Each of the remaining three Patagonian strains had a unique DNA profile, which differed from the collection strains tested, suggesting a different taxonomic position for each strain. Sequencing of the D1/D2 region indicated that these three strains belonged to Rhodotorula pinicola (100\% similarity to CRUB 1028), R. slooffiae (one mismatch with CRUB 1029) and to a novel yeast species closely related to $R$. lamellibrachii (six mismatches with CRUB $1032^{\mathrm{T}}$ ), for which the name Rhodotorula meli sp. nov. is proposed in this study. Further confirmation was obtained by ITS sequence analysis, which showed that $R$. meli sp. nov. CRUB $1032^{\mathrm{T}}$ (GenBank accession no. FJ807683) and $R$. lamellibrachii JCM $10907^{\mathrm{T}}$ (AB025999) differed by $22 \mathrm{nt}$. As depicted in Table 2, R. meli sp. nov. could be distinguished easily, on the basis of phenotypic characteristics, from $R$. lamellibrachii and other closely related species. R. meli differed from $R$. lamellibrachii in the assimilation of D-ribose, salicin, erythritol, D-mannitol, D-glucuronate, DL-lactate, succinate and citrate (positive for the former); and in the assimilation of maltose (weak), melezitose and growth at $30{ }^{\circ} \mathrm{C}$ (positive for the latter).

The yeast species closely related to $R$. meli sp. nov. seem to be mainly associated with aquatic habitats and, in particular, to marine environments. S. dacryoidea has been isolated exclusively from deep and surface seawaters of the Pacific, Indian (Fell et al., 1973) and Atlantic Oceans
(Gadanho et al., 2003). R. lamellibrachii and R. oryzae have been isolated less frequently; only one strain of each species is known. $R$. lamellibrachii was collected from a deep-sea tubeworm in the north-west Pacific Ocean (Nagahama et al., 2001), whereas $R$. oryzae was isolated from paddy rice (Bai et al., 2004). Despite numerous attempts, additional isolates of $R$. meli were not obtained in subsequent years, either from the same glacier or from nearby water bodies (Libkind et al., 2003, 2009b; Libkind, 2006), even when using specifically designed isolation media. Furthermore, R. meli sp. nov. was not even recovered during a comprehensive study on the diversity of cold-tolerant yeasts from Mount Tronador glaciers (de García et al., 2007). This indicates that the occurrence of $R$. meli sp. nov. in glacial meltwater is low and suggests that this may not be the original habitat of this yeast. Several studies on the yeast diversity of soil and phylloplane of native forests in northwestern Patagonia have been, and are being, carried out, but no strains of $R$. meli sp. nov. have been found so far.

\section{Latin diagnosis of Rhodotorula meli Libkind, van Broock et Sampaio sp. nov.}

Fungus Cystobasidiomycetous (Pucciniomycotina). In statu unicellulari cellulae elongate ad cylindraceae, $2-4 \times 4-7 \mu \mathrm{m}$. Mycelium verum non formatur. Fermentatio nulla. DGlucosum, D-galactosum, D-ribosum, L-arabinosum, sucrosum, $\alpha, \alpha$-trehalosum, salicinum, arbutinum, glycerolum, D-mannitolum, D-glucuronatum, DL-lactatum, succinatum et citratum assimilantur. L-Sorbosum, D-glucosaminum, Dxylosum, D-arabinosum, L-rhamnosum, maltosum, cellobiosum, melibiosum, lactosum, raffinosum, melezitosum, inulinum, amylum, erythritolum, ribitolum, xylitolum, Dglucitolum, galactitolum, inositolum, D-glucono-1,5-lactonum, ethanolum et methanolum non assimilantur. Substrata nitrogenica assimilate: L-lysinum; neque nitratum, nitritum, ethylaminum, creatinum et D-glucosaminum. Vitamina externa at crescentiam necessaria sunt. $25{ }^{\circ} \mathrm{C}$ crescit neque $30{ }^{\circ} \mathrm{C}$. Materia amyloidea iodophila non formantur. Urea finditur. Reactio Diazonii coerulei B positivum. Sequentiae acidi nucleici ITS et partium D1/D2 submonadis majoris ribosomalis typi in collectione sequentiarum acidi nucleici NCBI (www.ncbi.nlm.nih.gov) numeris FJ807683 et AY158654 depositae sunt. Cultura typica CBS $10797^{\mathrm{T}}$ in Centraalbureau voor Schimmelcultures, Ultrajecti, Hollandia, et JCM $15319^{\mathrm{T}}$ in Japanese Collection of Microorganisms, Japan, conservatur.

\section{Description of Rhodotorula meli Libkind, van Broock \& Sampaio sp. nov.}

Rhodotorula meli (me'li. meli meaning number four spelled in Mapuche aboriginal language, given that it is the fourth carotenogenic yeast species described from Patagonia).

After 7 days on MYP agar at $22{ }^{\circ} \mathrm{C}$, colonies are light pink, glistening, mucoid and smooth with entire margins. Cells are elongated to cylindrical $(2-4 \times 4-7 \mu \mathrm{m})$ and multiply 


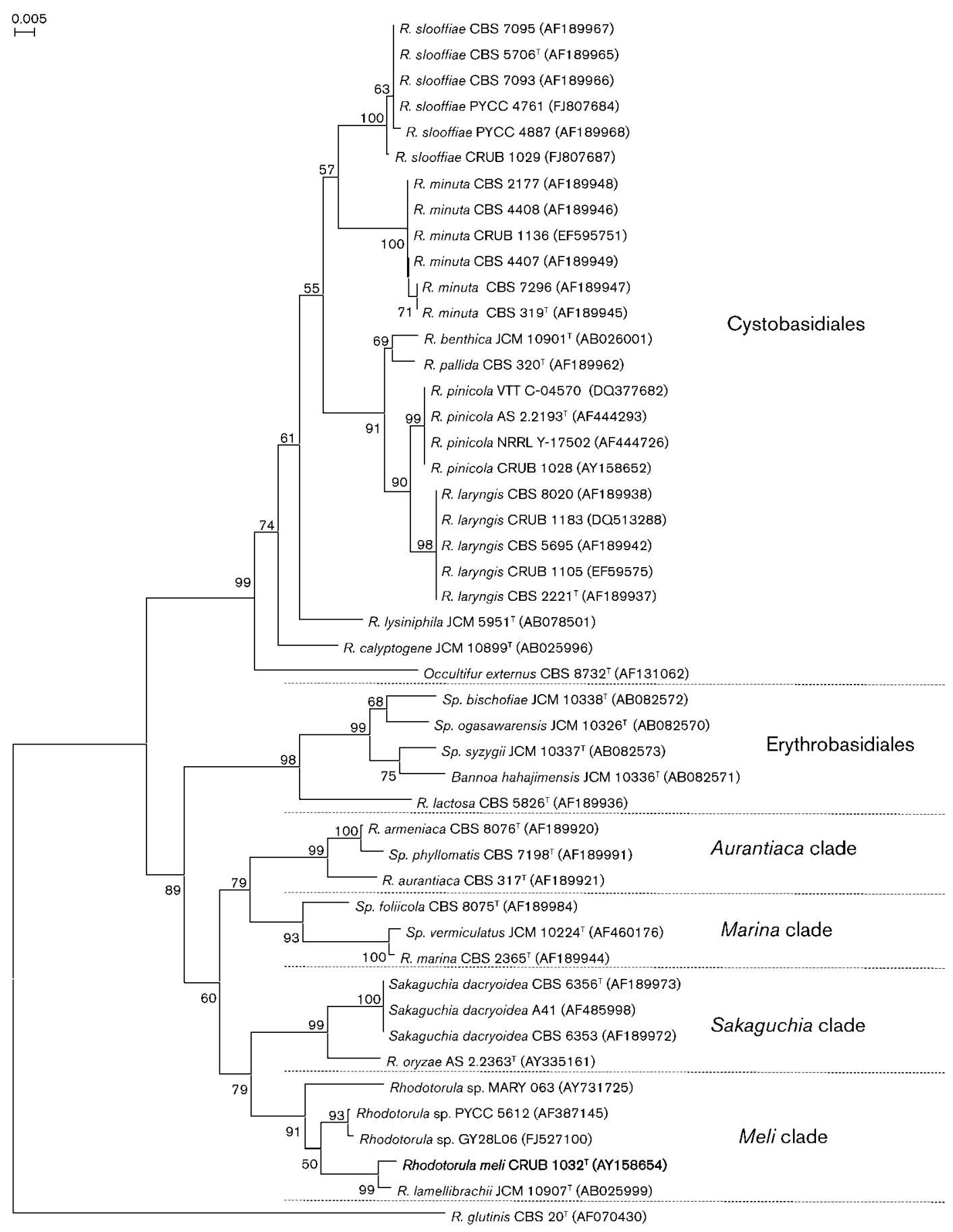

Fig. 1. Phylogenetic placement of $R$. meli sp. nov. and other Patagonian Rhodotorula spp. isolates (in bold) within the class Cystobasidiomycetes inferred using the neighbour-joining method based on alignment of nuclear DNA sequences of the D1/D2 region of the 26S rRNA gene. Evolutionary distances were computed using the Kimura two-parameter method. $R$. glutinis was used as the outgroup. Branch lengths are in substitutions per site. Numbers on the branches are bootstrap values (1000 replicates). GenBank accession numbers of the sequences are indicated after the species name. Sp., Sporobolomyces. Bar, 0.005 base substitutions per site.

by multilateral budding (Fig. 3). Glucose is not fermented. Mycelium or pseudo-mycelium are not produced. Glucose, D-galactose, D-ribose, L-arabinose, sucrose, $\alpha, \alpha$-trehalose, salicin, arbutin, glycerol, D-mannitol, D-glucuronate, DLlactate, succinic acid, citric acid, L-tartaric acid (slow and weak), D-tartaric acid (slow and weak), vanillic acid (slow 


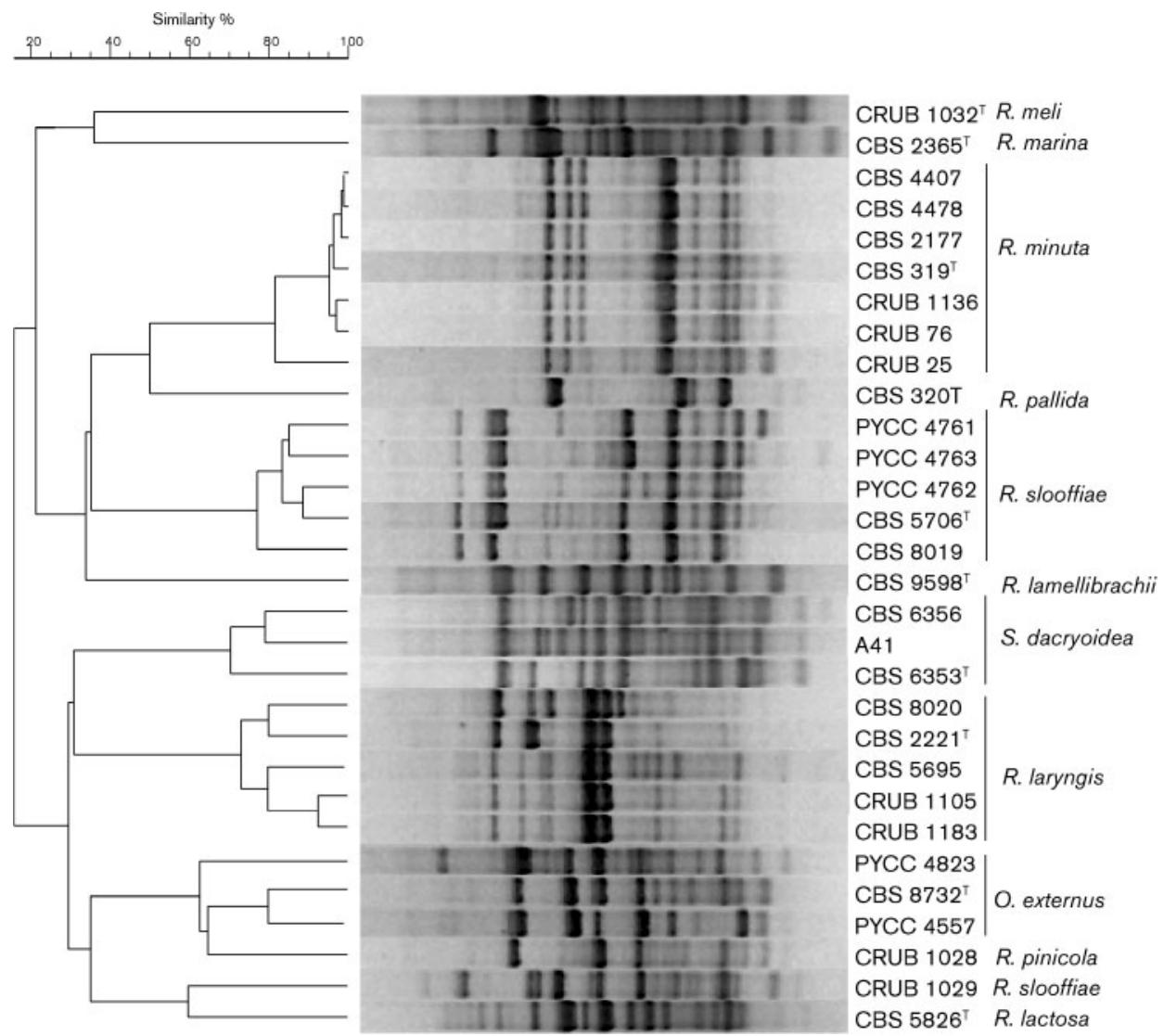

Fig. 2. MSP-PCR analysis of Patagonian isolates of the class Cystobasidiomycetes employing M13 primers. Cophenetic coefficient of 92.1 .

Table 2. Salient physiological differences between Rhodotorula meli sp. nov. and closely related species of the Cystobasidiomycetes

Species: 1, R. meli sp. nov. 2, R. lamellibrachii; 3, S. dacryoidea; 4, $R$. oryzae; $5, R$. marina. +, Growth; -, no growth; s, slow growth; W, weak growth; V, variable; ND, not determined. Physiological information for species other than $R$. meli sp. nov. was obtained from Bai et al. (2004), Nagahama et al. (2001) and the CBS database.

\begin{tabular}{|lccccc|}
\hline Characteristic & $\mathbf{1}$ & $\mathbf{2}$ & $\mathbf{3}$ & $\mathbf{4}$ & $\mathbf{5}$ \\
\hline D-Ribose & + & - & - & - & $\mathrm{S}$ \\
Maltose & - & $\mathrm{W}$ & $\mathrm{V}$ & - & + \\
Salicin & + & - & - & - & + \\
Melezitose & - & + & - & + & $\mathrm{W}, \mathrm{s}$ \\
Erythritol & + & - & - & - & - \\
D-Mannitol & + & - & + & + & + \\
D-Glucuronate & + & - & + & $\mathrm{ND}$ & - \\
DL-Lactate & + & - & $\mathrm{S}$ & - & - \\
Succinate & + & - & + & + & + \\
Citrate & + & - & + & + & $\mathrm{W}, \mathrm{s}$ \\
Growth at & - & + & - & + & + \\
$30{ }^{\circ} \mathrm{C}$ & & & & & \\
\hline
\end{tabular}

and weak), $p$-hydroxybenzoic acid (slow and weak) and $m$ hydroxybenzoic acid (slow and weak) are assimilated as carbon sources. Carbon sources not assimilated are

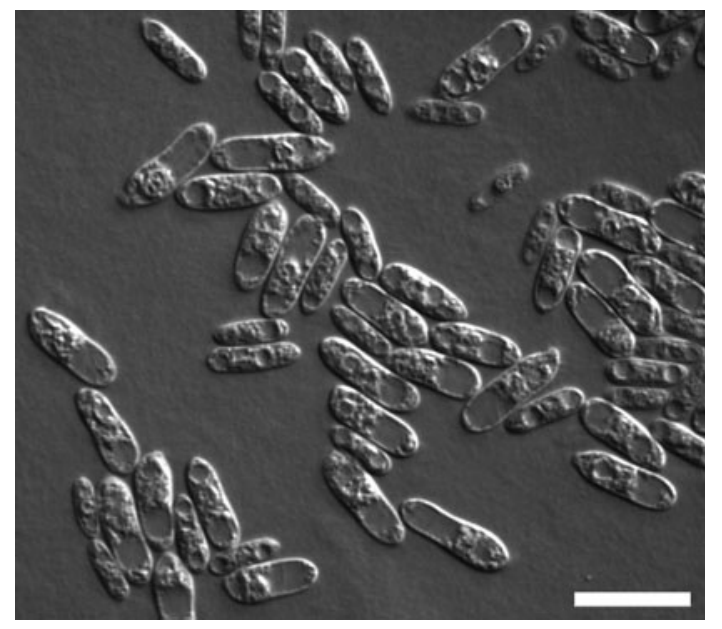

Fig. 3. Vegetative cells of $R$. meli sp. nov. CBS $10797^{\top}$ after 3 days in MYP agar at $20^{\circ} \mathrm{C}$. Bar, $10 \mu \mathrm{m}$. 
L-sorbose, D-glucosamine, D-xylose, D-arabinose, L-rhamnose, maltose, methyl $\alpha$-D-glucoside, cellobiose, melibiose, lactose, raffinose, melezitose, inulin, soluble starch, erythritol, ribitol, xylitol, D-glucitol, galactitol, inositol, glucono- $\delta$-lactone, methanol, ethanol, L-malic acid, $m$ tartaric acid, saccharic acid, mucic acid, veratric acid, ferulic acid, protocatechuic acid, catechol, gallic acid, salicylic acid, gentisic acid and phenol. L-Lysine is assimilated as a nitrogen source. No growth is observed using nitrate, nitrite, ethylamine, creatine or D-glucosamine as nitrogen sources. Growth in vitamin-free medium is negative. Mycosporine synthesis is positive. Grows at $25{ }^{\circ} \mathrm{C}$, but not at $30{ }^{\circ} \mathrm{C}$. PSC are not produced. Does not grow in $100 \mu \mathrm{g}$ cycloheximide $\mathrm{ml}^{-1}$. Urease activity is positive. Diazonium Blue B reaction is positive.

The type strain is CRUB $1032^{\mathrm{T}}\left(=\mathrm{CBS} 10797^{\mathrm{T}}=\mathrm{JCM}\right.$ $15319^{\mathrm{T}}$ ), isolated by D. Libkind in February 2009 from meltwater of the Ventisquero Negro glacier of the Tronador Mount in north-western Patagonia, Argentina $\left(41^{\circ} 24^{\prime} \mathrm{S} 71^{\circ} 83^{\prime} \mathrm{W}\right)$.

\section{ACKNOWLEDGEMENTS}

This work was accomplished with financial aid from the Universidad Nacional del Comahue (project B143) and Agencia Nacional de Investigaciones Científicas, ANPCyT (project PICT06-1176). The MINCYT-GRICES bilateral cooperation agreement and the ICSU/ TWAS/UNESCO short fellowship Programme in the Basic Sciences supported D. L.'s travel and subsistence in Portugal. Special thanks are given to Michael Weiß (University of Tübingen, Germany) for preparing the Latin diagnosis and to Celia Tognetti for reviewing the manuscript.

\section{REFERENCES}

Bai, F.-Y., Cai, Y., Wang, Q.-M. \& Ohkubo, H. (2004). Rhodotorula oryzae sp. nov., a novel basidiomycetous yeast species isolated from paddy rice. Antonie van Leeuwenhoek 86, 295-299.

Bauer, R., Begerow, D., Sampaio, J. P., Weiß, M. \& Oberwinkler, F. (2006). The simple-septate basidiomycetes: a synopsis. Mycol Prog 5, 41-66.

de Garcia, V., Brizzio, S., Libkind, D., Buzzini, P. \& van Broock, M. (2007). Biodiversity of cold-adapted yeasts from glacial meltwater rivers in Patagonia, Argentina. FEMS Microbiol Ecol 59, 331-341.

Fell, J. W., Hunter, I. L. \& Tallman, A. S. (1973). Marine basidiomycetous yeasts (Rhodosporidium spp. n.) with tetrapolar and multiple allelic bipolar mating systems. Can J Microbiol 19, 643657.

Felsenstein, J. (1985). Confidence limits on phylogenies: an approach using the bootstrap. Evolution 39, 783-791.

Fonseca, A. (1992). Utilization of tartaric acid and related compounds by yeasts: taxonomic implications. Can J Microbiol 38, $1242-1251$.
Gadanho, M., Almeida, J. M. G. C. F. \& Sampaio, J. P. (2003). Assessment of yeast diversity in a marine environment in the south of Portugal by microsatellite-primed PCR. Antonie van Leeuwenhoek 84, 217-227.

Hall, T. A. (1999). BioEdit: a user-friendly biological sequence alignment editor and analysis program for Windows 95/98/NT. Nucleic Acids Symp Ser 41, 95-98.

Kimura, M. (1980). A simple method for estimating evolutionary rates of base substitutions through comparative studies of nucleotide sequences. J Mol Evol 16, 111-120.

Libkind, D. (2006). Levaduras carotenogénicas de ambientes acuáticos de la Patagonia noroccidental Argentina. Aplicaciones biotecnológicas. $\mathrm{PhD}$ thesis, Universidad Nacional de Tucumán, Argentina (in Spanish).

Libkind, D., Brizzio, S., Ruffini, A., Gadanho, M., van Broock, M. R. \& Sampaio, J. P. (2003). Molecular characterization of carotenogenic yeasts from aquatic environments in Patagonia, Argentina. Antonie van Leeuwenhoek 84, 313-322.

Libkind, D., Gadanho, M., van Broock, M. R. \& Sampaio, J. P. (2005a). Sporidiobolus longiusculus sp. nov. and Sporobolomyces patagonicus sp. nov., novel yeasts of the Sporidiobolales isolated from aquatic environments in Patagonia, Argentina. Int J Syst Evol Microbiol 55, 503-509.

Libkind, D., Sommaruga, R., Zagarese, H. \& van Broock, M. R. (2005b). Mycosporines in carotenogenic yeasts. Syst Appl Microbiol 28, 749-754.

Libkind, D., Gadanho, M., van Broock, M. \& Sampaio, J. P. (2009a). Cystofilobasidium lacus-mascardii sp. nov., a basidiomycetous yeast species isolated from aquatic environments of the Patagonian Andes and Cystofilobasidium macerans sp. nov., the sexual stage of Cryptococcus macerans. Int J Syst Evol Microbiol 59, 622-630.

Libkind, D., Moliné, M., Sampaio, J. P. \& van Broock, M. (2009b). Yeasts from high altitude lakes: influence of UV radiation. FEMS Microbiol Ecol 69, 353-362.

Nagahama, T., Hamamoto, M., Nakase, T. \& Horikoshi, K. (2001). Rhodotorula lamellibrachii sp. nov., a new yeast species from a tubeworm collected at the deep-sea floor in Sagami Bay and its phylogenetic analysis. Antonie van Leeuwenhoek 80, 317-323.

Rayner, R. W. (1970). A Mycological Colour Chart. Kew, UK: Commonwealth Mycological Institute and British Mycological Society.

Saitou, N. \& Nei, M. (1987). The neighbor-joining method: a new method for reconstructing phylogenetic trees. Mol Biol Evol 4, 406425.

Sampaio, J. P. (1999). Utilization of low molecular weight aromatic compounds by heterobasidiomycetous yeasts: taxonomic implications. Can J Microbiol 45, 491-512.

Sampaio, J. P., Gadanho, M., Santos, S., Duarte, F., Pais, C., Fonseca, A. \& Fell, J. W. (2001). Polyphasic taxonomy of the genus Rhodosporidium: R. kratochvilovae and related anamorphic species. Int J Syst Evol Microbiol 51, 687-697.

Tamura, K., Dudley, J., Nei, M. \& Kumar, S. (2007). MEGA4: Molecular evolutionary genetics analysis (MEGA) software version 4.0. Mol Biol Evol 24, 1596-1599.

Yarrow, D. (1998). Methods for the isolation, maintenance and identification of yeasts. In The Yeasts, a Taxonomic Study, 4th edn, pp. 77-100. Edited by C. P. Kurtzman \& J. W. Fell. Amsterdam: Elsevier. 